\title{
DISCOVERY OF A BALKAN FRESH-WATER FAUNA IN THE IDAHO FORMATION OF SNAKE RIVER VALLEY, IDAHO.
}

\author{
By W. H. Dall.
}

In $1866 \mathrm{Gabb}^{1}$ described Melania taylori and Lithasia antiqua" from a fresh-water deposit on Snake River, Idaho Territory, on the road from Fort Boise to the Owyhee mining country. Collected by Mr. A. Taylor." He states that a small bivalve, perhaps a Sphaerium, was associated with them.

In $1870 \mathrm{Meek}^{2}$ described two species of Sphaerium, one from Fossil Hill, Nev. (included by King in his Truckee group), and one from Castle Creek, Idaho. Both these species occur in the Idaho material, and the presumption is strong that the two deposits are of the same age. In $1877 \mathrm{Meek}^{3}$ redescribed and figured them, considering their age as probably Miocene.

In 1882 C. A. White ${ }^{4}$ added another species, Latia dalli, from the Idaho deposits and referred the formation on King's authority to the Miocene. King ${ }^{5}$ does refer his Truckee group to the Miocene, but on another page ${ }^{6}$ he specifically refers the Idaho lake beds to the Pliocene. In this he is followed by Cope, ${ }^{7}$ who proposes for these beds an "Idaho group," which he regards as of middle or lower Pliocene age. As the molluscan fauna of the Truckee formation is practically the same as that of the Idaho formation, this conclusion would carry at least part of the Truckee into the Pliocene column.

In 1898 Lindgren ${ }^{8}$ gave the name Payette formation to plant-bearing lake deposits in the lower part of the Snake River valley, which he referred to the Miocene on the evidence of the flora as determined by Knowlton, and stated

\footnotetext{
${ }^{1} \mathrm{Gabb}$, W. M., Paleontology of California, vol. 2, p. 13, pl. 2, figs. 21-22, 1866.

${ }^{2}$ Meek, F. B., Acad. Nat. Sci. Philadelphia Proc. for 1870 , pp. 56-57, 1870 .

${ }^{3}$ Meek, F. B., U. S. Expl. 40th Par. Rept., vol. 4, pt. 1, p. 183, pl. 16, figs. 17-20, 1877.

${ }^{4}$ White, C. A., U. S. Nat. Mus. Proc., vol. 5, p. 100, pl. 5, figs. 17-20, 1882.

5 King, Clarence, U. S. Geol. Expl. 40th Par. Rept., vol. 1, p. 412, 1878.

${ }^{6}$ Idem, p. 440.

${ }^{7}$ Acad. Nat. Sci. Philadelphia Proc. for 1883, pp. 153-166, 1883.

${ }^{8}$ U. S. Geol. Survey Eighteenth Ann. Rept., pt. 3, p. 632, 1898 $33372^{\circ}-25-8$
}

that "this formation is probably not the same as Cope's Idaho formation, to which a Pliocene age was assigned." A footnote on the same page records the later conclusion that the Payette and Idaho formations represent two successive stages of the same lake and that it is not always easy to separate the two formations.

In the latest publication on the Payette formation R. W. Chaney, ${ }^{9}$ who has revised and added to the flora, concludes that the formation is Miocene, and states that this determination from the flora is also supported by the evidence of vertebrate fossils obtained by Buwalda.

In a discussion of Pliocene mammalian faunas from the Pacific coast and Great Basin provinces John C. Merriam ${ }^{10}$ says:

The Idaho formation is not as yet satisfactorily separated from the Payette Eocene or Miocene and from a Miocene or Pliocene stage which may intervene between the Payette and the Idaho. It is, however, quite certain that there exists over a large area of southwestern Idaho a formation several hundred feet thick which may show evidence of deformation and which contains a fauna of a stage representing either the latest Pliocene or the earliest Pleistocene.

The fresh-water molluscan fauna which is the subject of this paper apparently comes from the same beds that yielded the Pliocene or Pleistocene vertebrate fauna referred to by Merriam. The fresh-water deposits in Serbia, Hungary, and other parts of southeastern Europe are sometimes referred to in the literature as Miocene but are generally called Neogene without attempting to discriminate between Miocene and Pliocene ages. They are characterized by very numerous species of the genera Limnocardium, Congeria, Melanopsis, Neritina, and operculate forms related to Bythinia, none of which occur in North American lake beds so far as now known. In addition they contain a

9 Notes on the flora of the Payette formation: Am. Jour. Sci., 5th ser., vol. 4, pp. 214-222, 1922.

10 California Univ. Dept. Geology Bull., vol. 10, p. 432, 1917 
number of genera strikingly different from any now living in the fresh waters of the globe, such as Valenciennesia, Velutinopsis, Papyrotheca, Orygoceras, and Bagtivia. There are also a few of the smaller forms like Caspia which are found living or represented by close analogues in the Caspian Sea and Lake Baikal, both of which, it may be noted, are "relicten Seen."

The chief interest of the present paper lies in the discovery of some of these anomalous fresh-water genera in American lake beds of the Idaho formation, together with one or two curious forms not represented in Europe.

In 1909 A. A. Hinkley obtained from the wash of the Panuco River system, in the Mexican State of San Luis Potosi, some amnicoline shells which were recognized by H. A. Pilsbry as closely related to some of the forms from the Serbian lake beds, described by Brusina, and which were described by Pilsbry ${ }^{11}$ under the names Emmericiella and Pterides. It is not certain that these bleached specimens represent living species, as they might have been washed out of unconsolidated marl.

The genus Tryonia Stimpson, 1865, from the Colorado Desert fossil fauna, is undoubtedly an American type, but conchologically many of the shells named Prososthenia by Neumayr in 1869, from the Balkan lake beds, are almost identical with our Tryonia, which ranges from supposed Miocene deposits in Guatemala to the recent fauna of certain springs in California, to which it has retreated from the growing salinity of the former Lake Bonneville, now desert.

The United States Geological Survey recently received from Prof. F. A. Thomson, of the Idaho School of Mines, a piece of rock collected by W. H. Campbell from Castle Creek, Owyhee County, Idaho, and containing numerous freshwater shells.

A fine iconography of the Mollusca of the Balkan lake beds was published by the late Spiridion Brusina ${ }^{12}$ in 1902, and an examination of the Idaho material showed at once the presence of some of the remarkable European forms hitherto unknown in the Western Hemisphere.

The matrix consists of rather large rounded sand grains firmly cemented together and con-

\footnotetext{
11 The Nautilus, vol. 23, pp. 45-49, 1909.

12 Iconographia molluscorum fossilium in Tellure tertiaria Hungariae, Croatiae, Slavoniae, Dalmatiae, Bosniae, Hertzegovinae, Serbiae, et Bulgariae inventorum, pp. x, 30, pl. 30, Agram, 1902.
}

taining numerous fresh-water shells. The matrix is so flinty and the minute shells so extremely fragile that several specimens crumbled during the attempt to extricate them, and subsequent work was confined to the recording of such descriptive data as could be derived from an inspection of the more or less embedded individuals on the surface of the rock specimen.

The interest excited by this discovery led to an examination of all the material in the collection which had been obtained from this district, some of which had been tentatively reported on many years ago. Specimens were found which had been collected during the Fortieth Parallel Survey, by I. C. Russell, G. R. Mansfield, G. H. Eldridge and others, most of which had a matrix of fine-grained sandstone or shale. Curiously enough, none of them showed any trace of the Balkan species, except one found near Glenn's Ferry, in the Snake River canyon, which contained a fragment now recognizable as part of a species of Orygoceras. Though fossils were abundant, they represented only a few species which had been described by Gabb, Meek, and White in the publications above referred to. Taken altogether the number of lots is small, and their fossil content meager.

The condition of the matrix in the Thomson specimen is such that, while the generic relations of most of the fossils are determinable, for many of them it is not practicable to obtain sufficient data for specific determination, and some of the shells show evidence of having been worn or eroded before fossilization.

In enumerating the fossils of the Balkan type I have retained the nomenclature of Brusina, leaving questions of synonymy, if any, to be determined later.

\section{PELECYPODA. Genus SPHAERIUM Scopoli. Sphaerium rugosum Meek.}

Sphaerium rugosum Meek, Acad. Nat. Sci. Philadelphia Proc. for 1870, p. 56, 1870; U. S. Geol. Expl. 40th Par. Rept., vol. 4, pt. 1, p. 182, pl. 16, figs. 1, 1a, 1877.

White, C. A., U. S. Nat. Mus. Proc., vol. 5, p. 100, pl. 5, figs. 14-15, 1882; U. S. Geol. Survey Third Ann. Rept., p. 234, pl. 32, figs. 12-13, 1883.

Fossil Hill, Kawsoh Mountains, Nev.; Meek. Castle Creek, Owyhee County, Idaho; W. H. Campbell.

These specimens are identical with Meek's type. His locality was later included in the State of Idaho. 
Sphaerium meeki Dall, n. sp.

Plate XXVI, Figure 8.

Castle Creek, Idaho; Campbell.

A single valve of a small Sphaerium was obtained which is distinctly different from the preceding species. It is roundly rectangular in outline, the beak nearer the anterior end, low and smooth; sculpture of about ten cordlike concentric ridges with subequal interspaces, more crowded and less elevated toward the base; the valve thin, compressed, the anterior end somewhat more bluntly rounded than the other; the hinge and interior obscured by matrix. Longitude 5 millimeters; altitude 3 millimeters. U. S. Nat. Mus. catalog No. 333521.

Sphaerium idahoense Meek.

Sphaerium idahoense Meek, Acad. Nat. Sci. Philadelphia Proc. for 1870, p. 57, 1870; U. S. Geol. Expl. 40th Par. Rept., vol. 4, pt. 1, p. 183, pl. 16, figs. 1, 1a, 1877.

White, C. A., U. S. Nat. Mus. Proc., vol. 5, p. 100, pl. 5, figs. 12-13, 1882; U. S. Geol. Survey Third Ann. Rept., p. 34, pl. 32, figs. 14-15, 1883.

Castle Creek, Idaho, Meek; also Campbell.

This species is a much heavier shell than any of the recent Sphaeria and according to Meek has a sinuation of the palleal line like the old world Cyrenas, while the recent American species have a simple entire palleal line. I have not been able to detect any sinuation in the specimens I have examined. Meek was uncertain to which genus to refer it but tentatively placed it in Sphaerium. The shape is more like Cyrena.

GASTROPODA.

Family LYMNAEIDAE.

Genus LYMNAEA Lamarck.

Lymnaea? sp.

A shell having much the outline of Lymnaea vetusta Meek, with a distinctly truncate pillar and a gyrate internal axis, was obtained by G. R. Mansfield from the Salt Lake formation in the N. $\frac{1}{2}$ sec. 24 , T. 10 S., R. 43 E., in Idaho. It is perhaps not a Lymnaea, but the form is so obscured by a hard shaly matrix that a definite determination of the genus is not practicable.
Family PLANORBIDAE.

Genus PLANORBIS Müller.

Planorbis? sp.

Fragments and partial impressions of shells which may be planorboid are not rare in the material at hand, but they are not sufficiently well preserved to distinguish them from small or young specimens of Vorticifex.

\section{Subfamily POMPHOLIGINAE.}

Genus VORTICIFEX Meek.

Vortifex Meek, Acad. Nat. Sci. Philadelphia Proc. for 1870, p. 59; type Carinifex (Vortifex) tryoni Meek, loc. cit., sole example.

\section{Vorticifex tryoni Meek.}

Carinifex (Vortifex) tryoni Meek, Acad. Nat. Sci. Philadelphia Proc. for 1870, p. 59, 1870.

Carinifex (Vorticifex) tryoni Meek, U. S. Geol. Expl. 40th Par. Rept., vol. 4, pt. 1, p. 188, pl. 17, figs. 10, 10a-10c, 1877.

White, C. A., U. S. Nat. Mus. Proc., vol. 5, p. 100, pl. 5, figs. 8-9, 1882 .

Fossil Hill.

Vortifex, according to Meek, 1877, was a typographic error. It is extremely doubtful whether this form and its Pleistocene relatives have any distinctive characters separating them from Pompholyx Lea (not Gosse), Pompholopsis Call, and Parapholyx Hanna.

Generally the large Carinifex binneyi has been figured as typical of Vorticifex, but Meek did not originally place it in this group, which consisted only of the present species and its varieties.

An examination of the large series of recent Pompholyx in the National Museum reveals a great amount of variation. Nearly every lot of the recent shells contains a few more or less distinctly umbilicate specimens, though the typical form is imperforate. The Pleistocene specimens are smaller, more solid, and generally umbilicate; the Pliocene ones more distinctly so. One must recognize in this material, as with many other fresh-water gastropods, either one form with a multiplicity of varieties merging into one another, or a lot of species that can not be diagnostically separated. 


\section{Genus MEgASYSTROPHA Lea.}

Megasystropha Lea, Acad. Nat. Sci. Philadelphia Proc., 2d ser., vol. 8, p. 5, January, 1864. Type, Planorbis newberryi Lea, 1858.

Carinifex Binney, W. G., Smithsonian Misc. Coll. No. 143, pt. 2, p. 74, September, 1865. Type, Planorbis newberryi Lea, Acad. Nat. Sci. Philadelphia Proc. for 1858, p. 41, 1858.

December 9, 1863, while Mr. W. G. Binney was engaged in preparing an account of the land and fresh-water shells of the United States for the Smithsonian Institution, desiring the opinion and criticism of his colleagues, he induced Professor Henry to send out a set of proof sheets (not for sale) to a few persons who were interested in the study of mollusks. In the preface to these sheets Professor Henry, while explaining their purpose, remarks: "As a mere proof which will undoubtedly receive many corrections, these pages should not be quoted as authority or referred to as a published work."

These proofs were in page form printed on one side of the paper, and on the eleventh sheet occurs the absolutely nude name "Carinifex newberryi Lea." There was, prior to the issue of this proof, an Ancylus newberryi Lea, 1858, a Planorbis newberryi Lea, 1858, a Melania newberryi Lea, 1860, and a Goniobasis newberryi Lea, 1863, but no Carinifex newberryi, nor was there in the proof sheets referred to any indication which of the above-named species might be intended by Binney's Carinifex newberryi.

The first publication of the genus Carinifex occurred, as indicated in the preceding synonymy, in September, 1865. But Lea's name had been fully diagnosed and published in January or February, 1864. It would seem that, under the circumstances and according to the rules, Megasystropha should be accepted.

\section{Megasystropha binneyi Meek.}

Carinifex binneyi Meek, Acad. Nat. Sci. Philadelphia Proc. for 1870, p. 59, 1870.

Carinifex (Vorticifex) binneyi Meek, U. S. Geol. Expl. 40th Par. Rept., vol. 4, p. 187, pl. 17, figs. 11, 11a, 1877.

Fossil Hill.

Meek, in 1877, attempted to make this species the type of Vorticifex, but as it was not included in the subgenus as originally proposed, this, under the rules, can not be accepted.

This species differs from the typical Megasystropha in having the spire deeply sunken instead of elevated, and the peripheral edges rounded instead of carinate. This gives it a much more planorboid aspect. It may typify a section Paradines. Pompholopsis Call, 1888, typified by $P$. whitei Call, may form another section for fossil forms more turbinate, solid, and umbilicate than the recent type. The relations of Choanomphalus Gerstfeldt, a recent form of Lake Baikal, to the present group are in need of elucidation.

Subfamily PAYETTINAE.

Genus PAYETTIA Dall, n. gen.

Payettia dalli (White).

Latia dalli White, U. S. Nat. Mus. Proc., vol. 5, p. 100, pl. 5, figs. 17-20, 1882; U. S. Geol. Survey Third Ann. Rept., p. 45, pl. 32, figs. 37-40, 1883.

Fifty miles below Salmon Falls, Snake River; White. Castle Creek, Owyhee County, Idaho; Campbell. Also various other localities in the Idaho formation.

This is one of the relatively few species which appear to be widely distributed in the lake-bed deposits.

Though White recognized the differences between the Australasian and Japanese genus Latia and the present fossil, he nevertheless tentatively referred the fossil to the same genus.

Latia is a small fresh-water shell, with a short deck from which a prominent spurlike process projects. Payettia, on the other hand, has a simple deck like a Crepidula, but relatively smaller, and the shell grows to many times the size of Latia and is thin and undulated. The geographic distance between the two faunas alone would suggest the probable generic distinctness of the two forms, which is definitely confirmed by the shell characters. Payettia, however, is not represented in the Balkan fossil fauna.

\section{Family ANCYIIDAE.}

Genus ANCYLUS 0. F. Miuller.

\section{Ancylus undulatus Meek.}

Ancylus undulatus Meek, Acad. Nat. Sci. Philadelphia Proc. for 1870, p. 57, 1870: U. S. Geol. Expl. 40th Par. Rept., vol. 4, p. 186, pl. 17, figs. 12 a-b, 1882.

White, U. S. Geol. Survey Third Ann. Rept., p. 45, pl. 32, figs. 10, 10a, 1883.

Fossil Hill. .

I have not seen this species. 


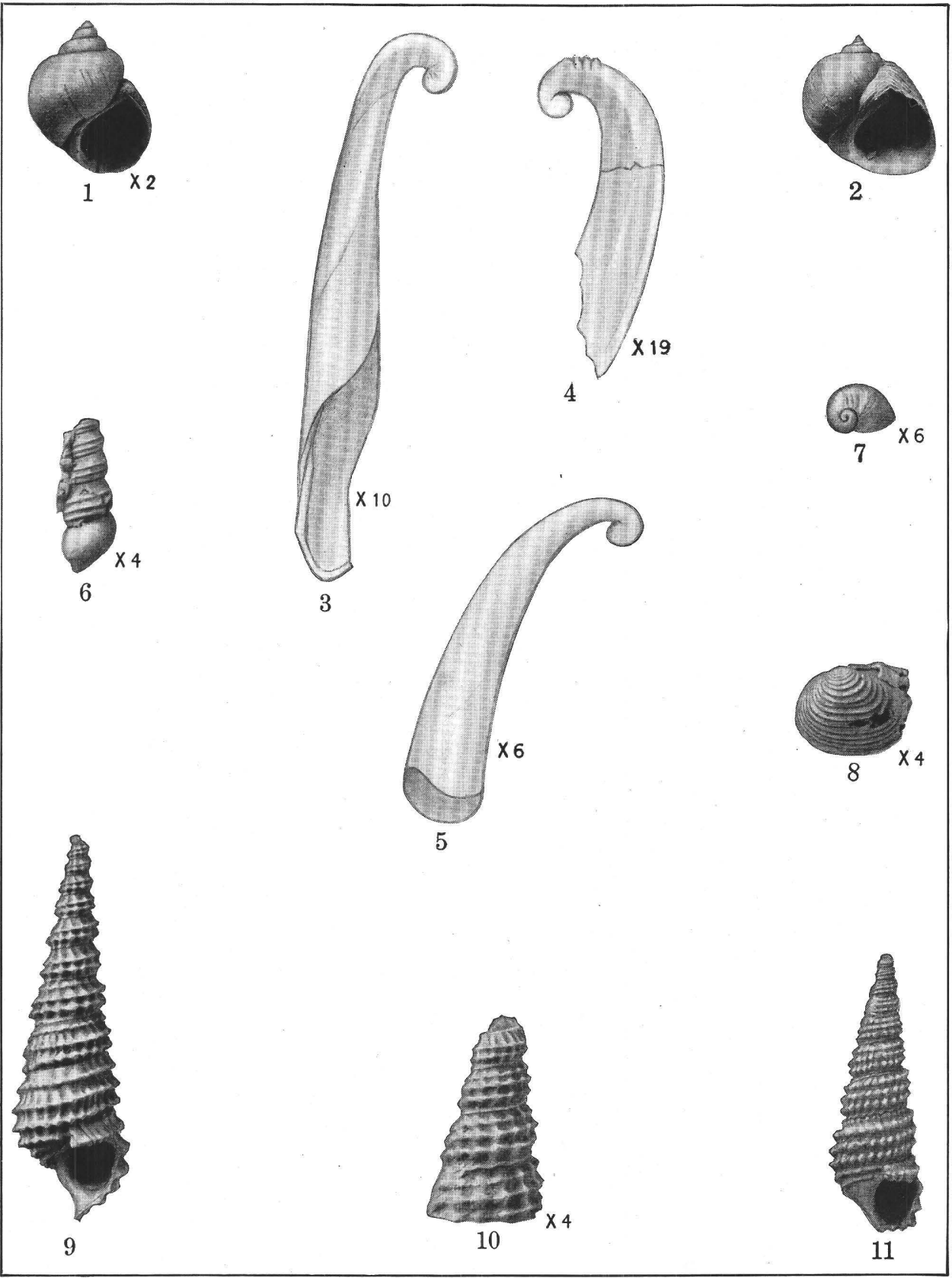

FOSSILS OF THE IDAHO FORMATION.

1. Lithoglyphus campbelli Dall.

2. Lithoglyphus aniiquus (Gabb).

3. Orygoceras (Ibicicornu) idahoense Dall.

4. Orygoceras (Ibicicornu) crenulatum Dall.

6. Apical whorls of Goniobasis taylori (Gabb).
7. Aphanotylus whitei Dall.

8. Sphaerium meeki Dall.

9. Goniobasis taylori (Gabb).

11. Goniobasis taylori (Gabb), upper part of 



\section{Family ORYGOCERATIDAE.}

\section{Genus ORYGOCERAS Brusina.}

Orygoceras Brusina, Beitr. Paläontologie Oesterr.Ungarns $u$. des Orients, vol. 2, p. 33, Wien, 1882; Iconographia molluscorum fossilium, $\mathrm{p}$. viii, pl. 2, 1882 .

Fischer, Manuel de conchyliologie, p. 735, fig. 504, 1885.

This extraordinary genus, resembling Parastrophia of the Caecidae among marine mollusks, but probably not operculate, is divisible into several quite distinct sections. No type was selected by the author, and therefore I select the example figured by Fischer, O. cornucopiae Brusina, as representing the typical section.

I. Section Orygoceras (strict sense). Shell tubular, with a small spiral apex, straight or slightly arcuate, cylindrical, gradually expanding, sculptured with regularly spaced transverse lamellae. Type O. cornucopiae Brusina.

II. Section Ibicicornu. Shell longitudinally subcarinate, with a dextral twist. Type O. fistula Brusina.

III. Section Bovillina. Shell smooth, with circular section, more or less arcuate. Type O. corniculum Brusina.

IV. Section Incilicornu. Shell nearly straight, longitudinally finely striate, slightly twisted near the apex. Type O. leptonema Brusina.

Members of sections I and IV have not yet been detected in America.

Orygoceras (Ibicicornu) idahoense Dall, n. sp. Plate XXVI, Figure 3.

Castle Creek, Owyhee County, Idaho; Campbell.

Shell minute, nearly straight, except the spiral nucleus of about one whorl, beyond which the whorl describes a semicircular arc equal to about half a revolution, beyond which the slowly enlarging tube becomes nearly straight; on the basal side of the spire a low rounded carina is initiated, which continues as far as the anterior end of the tube, making about half a revolution around it, the surface behind it appearing slightly flattened, the total aspect indicating a twist of the tube; the transverse section of the otherwise smooth tube, except for the slight indentation at the end of the carina, being circular. Longitude about 7 millimeters; diameter 1.5 millimeters. U. S. Nat. Mus. catalog No. 333522.

This resembles $O$. fistula Brusina but is longer and has the apex arched loosely, whereas in the Balkan species the apical part joins the nearly straight tube without an open arch.
Orygoceras (Ibicicornu) crenulatum Dall, n. sp.

Plate XXVI, Figure 4.

The apical portion and part of the succeeding tubular part of another species was found with the shell described above. The spiral apex is somewhat less involved, and the arch narrower; above the arch the periphery of the tube has four or five prominent transverse crenulations; the succeeding portion of the tube, in addition to the chief carina, has the beginning of a feebler second carina above it and near the periphery of the tube. The remainder of the shell was buried in the matrix and inaccessible. The length of the visible portion is about 3 millimeters. U. S. Nat. Mus. catalog No. 333523.

\section{Orygoceras (Ibicicornu) arcuatum Dall, n. sp.}

Plate XXVI, Figure 5.

Castle Creek, with the preceding species.

Shell minute, smooth, arcuate, rather rapidiy enlarging, the spiral part reduced to a minute bulb at the apex of the tube, the carina feeble but evident and becoming obsolete anteriorly; the twist in the tube well marked. Longitude 7.5 millimeters; diameter 1.7 millimeters. U.S. Nat. Mus. catalog No. 333524.

This is nearest to O. cnemopsis Brusina but is at least one-third longer, is less angular, and increases more rapidly in diameter.

\section{Orygoceras (Bovillina) tuba Dall, n. sp.}

Castle Creek, with the preceding species.

Shell small, smooth, ecarinate, the apex loosely coiled, forming hardly more than onehalf of a revolution; the cross section of the earlier part of the tube is slightly compressed laterally but later becomes circular; the aperture has its sides slightly arcuately produced, the edges receding between them; there is no trace of a carina, but a slight twist is perceptible. Longitude 8 millimeters; diameter of aperture 2 millimeters. U.S. Nat. Mus. catalog No. 333525.

This is nearest to O. corniculum Brusina, which is only 3 millimeters long and has a less even arcuation and a closely coiled nucleus, with no arch to speak of. A fragment of O.tuba on another piece of rock, without apex or aperture, is 7 millimeters long and indicates that a perfectly adult specimen might reach a length of over 10 millimeters. 


\section{Family MELANIIDAE.}

Genus GONIOBASIS Lea.

The forms described below are devoid of the anterior angularity of the margin of the aperture which suggested the generic name, but in a large number of the recent species now referred to the genus this feature is also absent, so it seems more probable that the fossil forms are related to the American genus than to the exotic typical Melania, which is not represented in the recent American fauna.

\section{Goniobasis taylori (Gabb).}

Plate XXVI, Figures 6, 9, 10.

Melania taylori Gabb, Paleontology of California, vol. 2, p. 13, pl. 2, fig. 21, 1865.

White, U. S. Nat. Mus. Proc., vol. 5, p. 100, pl. 5, fig. 3, 1882; U. S. Geol. Survey Third Ann. Rept., pt. 3, p. 55, fig. 3, 1883.

Goniobasis tayloriana Pilsbry, Nautilus, vol. 13, p. 66, 1899.

Castle Creek, Owyhee County, Idaho; A. Taylor, W. H. Campbell. Near Glenn's Ferry; I. C. Russell.

The typical $G$. taylori has sharp sculpture with the arcuate axial ridges sharp and prominent, usually with wider interspaces; on the last whorl there are six, on the preceding two whorls three, and on the earlier whorls two sharp spirals. The spire is elongate, tapering to an acute apex, and comprises ten or twelve whorls. The earlier ones are often eroded and appear nearly or quite smooth.

A variety of this species, more abundant at Castle Creek than the typical form, has the axial sculpture inconspicuous, the nodulation at the intersections rounded, and behind the last whorl all the whorls of the spire have three similar spirals. This may take the name $G$. taylori var. calkinsi (PI. XXVI, fig. 11). This was also collected in the Snake River canyon 1 mile east of Slick Bridge, on the south side of the river, by F. C. Calkins. U. S. Nat. Mus. catalog No. 333526.

\section{Genus MICROMELANIA Brusina.}

Micromelania Brusina, Fossile Binnen-Mollusken aus Dalmatien, Kroatien und Slavonien, p. 133, Agram, 1874. Type, M. cerithiopsis Brusina.

These are small subcylindric shells with numerous whorls and well-impressed suture. The aperture is simple. The original type is a sculptured shell, but of ten species figured in his Atlas, Brusina shows only one with pronounced sculpture. In the matrix of the material from Castle Creek there are a number of internal casts and fragments which might be referred almost indifferently to this genus or to Pterides, but in no specimen is the aperture preserved.

\section{Family HYDROBIIDAE. \\ Genus CASPIA Dybowski.}

Caspia Dybowski, Mal. Blätter, neue Folge, Band 10, p. 34, 1887. First species C. baeri Dybowski, p. 36 , pl. 3, figs. $4 \mathrm{a}-\mathrm{b}$, which may be taken as the type.

This small operculate is found living in the Caspian Sea, and numerous species occur in the Balkan fresh-water deposits. Internal casts which might belong to a species like that (unnamed) which is figured in Brusina's Atlas, Plate XI, Figures 14-15, occur in the Castle Creek material but can not be positively identified.

\section{Genus NEMATURELLA Sandberger.}

Nematurella Sandberger, Conchylien der Vorwelt, p. 575,1874 . Sole example, $N$. flexilabris Sandberger, p. 575, pl. 20, figs. 24, $24 c$.

Brusina, Atlas, p. viii, pls. 9, 11, 29, 1902.

Two worn specimens from the Castle Creek material are very close to the unnamed species figured in Brusina's Atlas, Plate XI, Figure 26, but are hardly well enough preserved for description.

\section{Genus SANDRIA Brusina.}

Sandria Brusina, Atlas, p. ix, pl. 9, figs. 22-27, 1902. Type, S. kochi Brusina, pl. 9, figs. 22-24.

These are small shells, much resembling minute Bythinella. I have not been able to find a reference to the earlier description of $S$. kochi or the genus Sandria. Three species in a more or less imperfect state of preservation are represented in the Castle Creek material if their resemblance to Brusina's figures may be trusted.

Subfamily LITHOGLYPHINAE.

Genus LITHOGLYPHUS Mühlfeldt.

Lithoglyphus (Mühlfeldt MS.) Hartmann, in Sturm's Fauna Deutschl., vol. 6, Heft 5, p. 57, 1821. Ziegler, in Menke, Synops., p. 42, 1830. Type, Paludina naticoides Ferussac.

\section{Lithoglyphus antiquus (Gabb).} Plate XXVI, Figure 2.

Lithasia antiqua Gabb, Paleontology of California, vol. 2, p. 13, pl. 2, fig. 23, 1865.

White, U. S. Nat. Mus. Proc., vol. 5, p. 100, pl. 5, fig. 4, 1882; U. S. Geol. Survey Third Ann. Rept., pt. 3, p. 59, pl. 32, fig. 4, 1883.

This is one of the most widely distributed and conspicuous members of the fresh-water 
fauna of the Idaho formation. It is a typical Lithoglyphus and the first genuine member of that genus to be reported from the Western Hemisphere. The species reported by authors from South America in the Recent fauna belong to quite different genera.

Lithoglyphus campbelli, Dall, n. sp. Plate XXVI, Figure 1.

Mouth of King Hill Creek near Glenn's Ferry, Snake River canyon, Idaho, U. S. Geol. Survey station 3486: I. C. Russell; very abundant.

Shell small, solid, with a rather acute apex, a pustular nucleus, and about five well-rounded whorls; suture distinct, the whorl in front of it flattened a little, giving a slightly turrited aspect to the spire; last whorl much the largest, naticoid; surface smooth except for incremental lines; base rounded, imperforate; aperture subovate, simple, the margins sharp, the inner and outer lips connected over the body by a thick layer of callus. Altitude, 11 millimeters; maximum diameter, 8 millimeters; aperture, 6.5 millimeters. U. S. Nat. Mus. catalog No. 333527.

Named in honor of W. H. Campbell, collector of the Castle Creek material.

Family VALVATIDAE.

Genus Valvata 0. F. Müller?

Brusina refers to Valvata a considerable number of turbinate shells from the Balkan deposits, figuring them on his Plates XIII and $\mathrm{XIV}$. In general, they appear heavier and thicker than the recent shells familiar to us, and some of them with a different type of sculpture remind one of the marine trochoid
Machaeroplax Friele. One such specimen occurs partly embedded in the Castle Creek material, the aperture and base inaccessible, the upper surface showing about three whorls encircled by two inconspicuous carinae. It is probable that with a better knowledge of these animals a portion at least of the species will prove to be separable from typical Valvata.

Genus APHANOTYLUS Brusina.

A phanotylus Brusina, Jour. de Conchyliologie, vol. 41, pp. 179, 182, 1893 . Type, A. cossmanni Brusina, op. cit., p. 185; Atlas, p. v, pl. 14, figs. 22-27, 1902.

These are minute planorboid shells with a closed or nearly closed umbilicus, having a remarkable resemblance to the marine genus Pseudorotella Fischer.

\section{Aphanotylus whitei Dall, n. sp.}

Plate XXVI, Figure 7.

Castle Creek, Owyhee County, Idaho; W. H. Campbell.

Shell minute, of about two whorls, the nucleus hardly raised above the flattened spire, the surface smooth, the suture inconspicuous, the last whorl rather rapidly enlarging; the aperture subcircular with sharp-edged margin and no lirae internally; base well rounded, imperforate. Diameter, 1.6 millimeters; height, 1.2 millimeters. U. S. Nat. Mus. catalog No. 333528 .

Another species, represented by broken specimens in the matrix, has a raised cord running spirally in front of the suture and somewhat separated from it. It is a larger shell than $A$. whitei. 